\title{
The Authority of Aceh Government in Managing Zakat as a Source of Local Revenue
}

\author{
Fuadi \\ Law Faculty of Samudra University Meurandeh Campus - Langsa - Aceh - Indonesia
}

\begin{abstract}
Law Number 11 of 2006 on Governing of Aceh authorizes the government to manage zakat as a source of local revenue. However, at the level of implementation it raises a variety of legal issues. On the one hand, zakat as a local revenue adheres to the provisions of local financial management, while on the other side, zakat as part of the religious issues. This study is aimed to in-depth analyze what the legal basis for the establishment of the authority of the Government of Aceh to manage zakat as a local revenue and how its implications to the regulations of zakat as revenue in Aceh. The result is that the legal basis for granting the authority to manage zakat as local revenue can be seen from the perspective of Administrative Law, which is the attribution authority based on legislation. While from the perspective of Islamic law, it is not in accordance with practices in the Islamic government (caliphate),. Since Indonesia is not based on Islamic Law, therefore the role of community should be considered in managing zakat, in addition to the role of the state (government).

Keywords: authority, the Government of Aceh, Zakat, the local revenue.
\end{abstract}

\section{Background}

In line with one of the demands for reform in Indonesia in 1998, the regional administration should be transformed from a centralized system to a decentralized system based on Article 18 of the Constitution of the Republic of Indonesia 1945. It is an entry point for regional governments to regulate and administer their own government according to autonomy and assistance tasks. This means that the regional government in addition to conducting its own domestic affairs as well as possible, doing construction, and so on to improve the welfare and prosperity of the region, also organizes the tasks entrusted to the Central Government. ${ }^{1}$ In normative, it is expected the emergence of a more democratic climate of local government administration.

Related to this, it is interesting to study about regional government system imposed in Aceh, which is called autonomous and special privilege region. Granting both statuses by the central government as the solution of prolonged Aceh conflict. ${ }^{2}$

Granting of privileges ${ }^{3}$ covers four main areas, namely:

First, the implementation of religious life;

Second, implementation of indigenous life;

Third, implementation of education, and

Fourth, the role of the ulamas in the determination of regional policy. ${ }^{4}$

The first privilege as the the organization of religious life is manifested in the form of the implementation of Islamic law for followers in society.

One application of Islamic law ${ }^{5}$ in Aceh is the authority of local government to the manage zakat as ruled in Law No. 11 of 2006 on Governing Aceh. This authority is not given or found in other parts of Indonesia, so-called special autonomy authority, namely the rules and special authority (different) with the rules given to other provinces. ${ }^{6}$

If detailed, there are two special autonomous authorities. First, specificity under the authority of the Government of Aceh and regency/city that will be governed by Aceh Qanun or qanun of regency/city. Second, the specificity under the authority of the central government that will be governed by the laws and regulations at national level that is appropriate for it. ${ }^{7}$

\footnotetext{
${ }^{1}$ S.Prajudi Atmosudirjo, Hukum Administrasi Negara, Cetakan ke-10, (Jakarta : Ghalia Indonesia, 1995), p. 115

${ }^{2}$ H.Rusjdi Ali Muhammad, Revitalisasi Syari'at Islam di Aceh Problem,Solusi and Implementasi Menuju Pelaksanaan Hukum Islam di Nanggroe Aceh Darussalam, (Ciputat : Logos Wacana Ilmu, 2003), p.45

${ }^{3}$ Al Yasa Abubakar, "Pelaksanaan Syariat Islam di Aceh (Sejarah and Prospeknya)," dalam Safwan Idris (et.al.), Syariat di Wilayah Syariat , (Banda Aceh: Dinas Syariat Islam and YUA, 2002), pp. 26-51

${ }^{4}$ See: Article 3 paragraph (2) Law No. 44 of 1999 on Implementation Special Status of Province of Aceh

${ }^{5}$ See: Hasan Ahmad al-Khatib, al-Fiqh al-Muqarran (Kairo: Dar al-Ta'lif, 1957), p. 8. See: Ahmad Hasan, The Early Development of Islamic Jurisprudence (Islamabad: Islamic Research Institute, 1994), pp. 1-10.

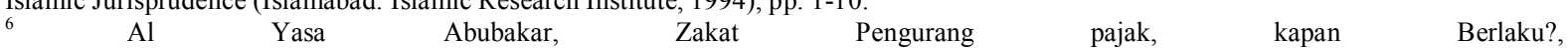
http://mpu.acehprov.go.id/index.php?option=com_content\&view=article\&id=78:zakat-pengurang-pajak-kapan-berlaku\&catid, accessed on August $19^{\text {th }}, 2013$

${ }^{7}$ Ibid.
} 
Zakat is one part of a special autonomy because zakat management is unlike arrangements that apply nationally. There are three interesting things regarding "zakat issues" stipulated in Law No. 11 of 2006 on the Governing of Aceh, namely:

1. Article 180 paragraph (1) letter d states: "Zakat is one source of the Aceh Regional Income and Regency/City's Revenue";

2. Article 191 states: "Zakat, waqf property, and the property are managed by Aceh Baitul Mal and Regency/City's Baitul Mal, which is governed by Qanun";

3. Article 192 states: "Paid Zakat is a deduction of the amount of payable income tax of the taxpayer."

As a result of the determination of zakat management policy is the authority of local governments and as a source of regional revenue, it is interesting to study this problem legally, since being debated for academics and the wider community in Aceh. There are those who do not agree with this policy, because they will used to finance the state budget as well as other revenue sources. While public understanding of zakat is set up by the $\mathrm{Al}$ - Quran and Al - Hadith to be distributed to eligible asnaf (mustahik). Zakat is a religious obligation as mahdah worship, and it is something sacred that should not be mixed with Subhat. Then, even if the central government gives authority to local governments (Aceh) to impose Islamic law, but the local government system (Aceh) does not adhere to the Islamic system of government (caliphate), because Aceh is one of the province is part of the Republic of Indonesia, which system of government is based on the ideology of Pancasila and the 1945 Constitution of the Republic of Indonesia.

\section{Problems}

Based on the above description, there are two problems that are studied in this paper, namely First: what is the legal basis of regional authority (Aceh) in managing zakat as regional revenue? Second: how are the implications of zakat management as a source of local revenue in Aceh?

\section{Research Method}

The research method used in this paper is the juridical-normative, legal research that laid the law as a system of norms that is building on the principles, norms, rules and laws, court decisions, treaties and doctrines. ${ }^{8}$ According to Johnny Ibrahim, the juridical-normative is a scientific procedure to find the truth of scientific logic based on the normative perspective, where the object of research is the law itself. The approach used in this study is a comparative approach and statute approach, and history approach.

Normative studies use secondary data to examine library materials. Normative legal research includes a study of the inventory of positive law, a study of the principles of law, legal research to find law in concreto, systematic research on law, legal research on the extent of vertical and horizontal synchronization, and comparison study of positive law. ${ }^{9}$

This prescriptive study offers concept to solve a problem (problem solving) and not merely descriptive (just to describe something as it is). ${ }^{10}$ The nature of prescriptive study is to highlight something (object) that is aspired to or supposed to. ${ }^{11}$ That is meant to illustrate the problems of Aceh government authority in the management of zakat as a source of revenue.

It also used qualitative research methods ${ }^{12}$ and the analysis does not depend on data in terms of the amount, but the existing data is analysed from various perspective in holistic. Nawawi ${ }^{13}$ said that qualitative research is a whole concept to express something done by collecting data in reasonable circumstances (natural setting) by using a systematic way of working, directional and can be qualitatively justified, so it does not lose its scientific nature.

Legal materials used in this study are consisted of:

a. The primary legal materials, which is a major legal materials and binding, covers among others: the 1945 Constitution of the Republic of Indonesia; Law No. 44 of 1999 on Implementation Special Status of Province of Aceh, Law No. 11 of 2006 on Governing of Aceh, Law No. 23 of 2011 on Zakat Management, Home Affairs Minister Regulation No. 13 of 2006 on Regional Financial Management, Regulation of the Minister of Home Affairs Number 37 of 2009 on Guidelines for Organization and Work of Privileged Institutions, Aceh Qanun No. 10 of 2007 on Baitul Mal, Aceh Governor Regulation No. 60 of 2008 on Mechanism of Zakat Management, Regulation of the Governor of Aceh No. 1 of 2008 on the Financial

\footnotetext{
${ }^{8}$ Mukti Fajar ND \& Yulianto Achmad, Dualisme Penelitian Hukum Normatif \& Empiris, (Yogyakarta : Pustaka Pelajar, 2010), p.34

${ }^{9}$ Ronni Hanitijo Soemitro, Metodologi Penelitian Hukum and Jurimetri, (Jakarta : Ghalia Indonesia, 1990), pp. 12-13; see. Soerjono Soekanto and Sri Mamuji, Penelitian Hukum Normatif, (Jakarta: Rajawali, 1985), p. 15

${ }^{10}$ M.Solly Lubis, Filsafat Ilmu and Peneltian, (Jakarta : PT.Softmedia, 2012), p.107

${ }^{11}$ Ibid, p. 3

${ }^{12}$ Sri Gambir Melati Hatta, Beli Sewa sebagai Perjanjian Tak Bernama, Panandgan Masyarakat and Sikap Mahkamah Agung Indonesia, (Bandung: Alumni, 1999), p. 20.

${ }^{13}$ H. Hadari Nawawi and Himi Martini, Penelitian Terapan, (Yogyakarta : Gajah Mada University Press), $1996, \mathrm{p} 175$.
} 
Management, Regulation of the Governor of Aceh No. 55 of 2010 on Procedures for Acceptance and Disbursement of Zakat on Aceh Treasury and Aceh Governor Regulation No. 4 of 2011 on the Shariah Advisory Council and other implementing regulations .

b. Secondary legal materials, ie materials that can explain the law to the primary legal materials, such as books, the results of previous studies on the management of zakat, the scientific writings of Islamic law in general.

c. Tertiary legal material is legal materials that provide instructions or a meaningful explanation of the primary and secondary legal materials, such as dictionaries, encyclopedias and others.

Analysis of the data, the collected datas are sorted and processed, then analyzed and interpreted normatively, logically and systematically using inductive and deductive methods.

\section{Result and Discussion}

\section{Legal Standing of Determination of (Aceh) Regional Authority in Managing Zakat As Local Revenue.}

Indonesia is a rule of law state based on Pancasila. According to Tahir Muhammad Azhari, the characteristics of Pancasila Rule of Law State is a very close relationship between religion and the state, which rests on the Belief in God Almighty-freedom of religion-atheism is not allowed and communism is forbidden, the principle of kinship and harmony takes precedence. The main elements of Pancasila state, include: Pancasila, constitutional system, equality, and independent of court. ${ }^{14}$ This means bringing the consequences that anything done by the government (the State) should be based on the law, which in this case are the established and enforced rules. In line with the opinion of Hugo Grotius (de Groot) as natural legal expert, that if the state will form the law then the content of the law must be addressed to achieve what the destination of state. ${ }^{15}$ This provision is intended to prevent arbitrariness and arrogance of power, whether committed by state or citizens.

In the State of Law, the law is a supreme commander in the administration of the state. According to Bagir Manan, the conception of the modern rule of law state is a combination of rule of law and the concept of the welfare state. In this concept, the tasks of state or government are not solely as a security guard or public interests, but also take responsibility of social justice, general welfare and prosperity of the people as much as possible. ${ }^{16}$

In the perspective of the welfare state and the rule of law, government is burdened with the obligation to hold the public interest or social welfare efforts, which in carrying out the obligations, the government is given the authority to intervene in people's lives, within the limits allowed by law. Along with the authority to intervene, the government is also given the authority to make and enforce the laws or legislation.

Conceptually, the term of authority or authorities are often equated with the term in Dutch "bevoegdheid" (which means authority or power). The authority is a very important part in Constituional Law (Administrative Law), as the government can perform its functions only on the basis of earned authority. The validity of the government action is measured by the authority set out in legislation. The authority matters can be seen from the State Constitution that gives legitimacy to the Public Bodies and Institutions of the State in carrying out its functions. The authority is the capability of act provided by applicable law to perform legal acts and relationships. ${ }^{17}$

The explanation of the concept of authority, can also be approached through the study of the source of authority and justification concepts of governmental power. Theory of source of authority include attribution, delegation, and mandates.

Prajudi Atmosudirdjo argues about the definition of authority in relation to the authority as follows:

The authorization is what is called a formal power, power from Legislative Powers (given by the Act), or of the Executive Power/Administrative. The authorization is the whole power of the particular class of persons or particular area of government affairs, while the authority is only on something specific parts. On authorization contained some authorities. The authority is the power to perform public law action". ${ }^{18}$

Indroharto argued that the authority acquired by attribution, delegation, and mandates, which is described as follows:

The authority obtained by "attribution", namely the provision of a new government authority by a provision in the legislation. So, here are born/ created a new government authority. In the delegation, there was a transfer of an existing authority which authorized by the Board or the Administrative Position has obtained a government

\footnotetext{
${ }^{14}$ Muhammad Tahir Azhari, Negara Hukum Suatu Studi tentang Prinsip-prinsipnya Disee dari Segi Hukum Islam, Implementasinya pada Periode Negara Madinah and Masa Kini, (Jakarta: Prenada Media, 2003), p. 102

${ }^{15}$ Ida Nurlinda, Prinsip-Prinsip Pembaruan Agraria, Perspektih Hukum, (Jakarta : PT Rajagrafindo Persada, 2009 ), p. 11

${ }^{16}$ Bagir Manan, Politik Perunandg-Unandgan dalam Rangka Mengantisipasi Liberalisasi Perekonomian, (Bandar Lampung: FH-UNILA, 1996), p. 16

${ }_{17}^{17}$ SF. Marbun, Peradilan Administrasi Negara and Upaya Administrasi di Indonesia, (Yogyakarta : Liberty, 1997$)$, p. 154.

${ }^{18}$ Prajudi Atmosudirdjo, Hukum Administrasi Negara, (Jakarta : Ghalia Indonesia, 1981), p. 29
} 
authority attributively, to the Agency or other State Administrative Position. Thus, a delegation is always preceded by the presence of attribution of authority. In the mandate, there does not occur a new empowerment or delegation of authority from one Board or Administrative Position to the other. ${ }^{19}$

Based on the above description, constitutionally Indonesia is a nation that very respect of the religious life of its citizens, and therefore the authorization of the application of Shari'a in Aceh based on Article 18B of the 1945 Constitution of paragraph (1), "the Unitary State of Republic of Indonesia recognizes and respects local goverment units that are special or previleged and that are regulated by the law". To carry out the mandate, the government issued Law No. 44 of 1999 on Implementation of Regional Previleged Features of Aceh province and Law No. 11 of 2006 on the Governing of Aceh. Based on these laws, the government gives authorization to the local (Aceh) government to impose Islamic law and one of them is to manage zakat as a source of local revenue.

To implement these two rules concerning the management of zakat, then will be regulated in qanun ${ }^{20}$ through Islamic law legislation (taqnin). ${ }^{21}$ Local governments and the Parliament has enacted Aceh Qanun No. 10 of 2007 on the Baitul Mal. Aceh government regulates management of zakat in Aceh Qanun No. 10 of 2007, which means it is not regulated in specific qanun. Thus, law No. 10 of 2007 sets two issues, the first, it sets of institution of Baitul Mal as a non structural local agency, that has function to manage zakat and other religious treasures; the second: governing the management of zakat. In contrast to earlier, when Law No. 18 of 2001 on Special Autonomy in Aceh still valid, zakat management was separately regulated in the Aceh Qanun No. 7 of 2004 on Zakat. This Qanun is subsequently canceled and replaced by Aceh Qanun No. 10 of 2007 on the Baitul Mal.

In Article 24, paragraph (2) states: "all income of zakat managed by Aceh Baitul Maal is a source of local revenue that must be deposited into the General Treasury of Aceh". Similarly, the provision of Article 25 paragraph (2): "all income of zakat managed by Regency/City Baitul Maal is a source of regency/municipality revenue to be deposited into the General Treasury of Regency/City."

The government wants zakat in Aceh is levied by the Local Government as had been done in the caliphate, so zakat is designated as a source of local revenue. However, there is a fundamental difference between the Aceh administration system with Islamic Government System practiced by the Prophet Muhammad and Khulafah al Rasyiddin. Aceh is one of the province in the Republic of Indonesia based on Pancasila and the 1945 Constitution of the Republic of Indonesia, which means the government of Aceh is not an Islamic State. According to M. Solly Lubis, this idea (zakat is managed by the state) is not fully wrong, but the problem is how to align zakat management not violate the provisions of Islamic law. ${ }^{22}$

When compared with other regions, this authority is not found as a nationally regulated in Law Number 23 Year 2011 concerning Zakat management. According to Law No. 23 of 2011, Zakat is managed by the National Amil Agency of Zakat and the Amil Institute of Zakat. National Amil Agency of Zakat is a nonstructural government agency that is independent and responsible to the President through the Minister of Religion, located in the capital city of state. ${ }^{23}$ In the implementation of zakat management at the provincial and regency/city, the government forms the Provincial National Zakat Agency and the National Zakat Agency of regency/city. Provincial National Zakat Agency established by the Minister of Religion at the proposal of the governor after a consideration of the National Zakat Agency. ${ }^{24}$ National Zakat Agency of regency/city is established by the Minister or officials appointed at the proposal of the regent/mayor after a consideration of the National Zakat Agency. ${ }^{25}$

To assist the National Zakat Agency in the collection, distribution, and utilization of zakat, the public could form the Institute of Amil Zakat. Establishment of Institute of Amil Zakat must obtain the permission of the Minister or officials appointed by the Minister of Religious Affairs. ${ }^{26}$ Thus it is clear that the authorization

\footnotetext{
${ }^{19}$ Indroharto, Usaha memahami Unandg-Unandg tentang Peradilan Tata Usaha Negara, (Jakarta : Pustaka Harapan, 1993), p. 90

${ }^{20}$ See. Article 191 paragraph (1) and (2) UUPA 2006. Taqnin in etimology means rule, statude, code.. Hans Wehr. A Dictionary, p. 791; while in terminology means a group of rules that is devised to manage human affairs in society relationship. These rules must be obey, respected, and applicated to the public, and the law apparatuses can enforce people to respect it. Muhammad al-Ghazali (et.al), Nizam Itsbatt al-Da'wa wa Adillatuh fi al-Fiqh al-Islami wa al-Qanun, $1^{\text {st }}$ Ed., (Iskandariyyah: Dar al-Da'wah, 1996), p. 28. Qanun is defined by Article 1 number 21 UUPA as the legislation regulation similar to regional (local) regulation that governs the implementation of governance and society lives in Aceh.

${ }^{21}$ Taqnin (ethymology) is legistilation, law making, codification. Hans Wehr, A Dictionary of Modern Writen Arabic, J. Milton Cowan (ed.), (Wesbaden: Otto Harrassowitz, 1971), p. 791. While in terminology means an effort to compile or codify the rules in one written book or in one legislation. Abd. al-Hamid Mutawalli, Azmah al-Fikr al-Islamy fi al-'Asr al-Hadith (T.tp: al-Hay'ah al-Misriyyah al-Ammah li alKitab, 1985), p. 22

${ }^{22}$ Interview with M. Solly Lubis, (Professor in School of Law University of North Sumatera) on September $28^{\text {th }}, 2013$.

${ }^{23}$ See. Article 5 paragraph (1), (2) and (3) Law No. 23 of 2011 on Zakat Management.

${ }^{24}$ Ibid, Article 15 paragraph (1) and (2).

${ }^{25}$ Ibid, paragraph (3)

${ }^{26}$ Ibid, See : Article 17 and Article 18.
} 
of zakat management for the Government of Aceh is different from other regions or referred to Aceh as an exception (lex specialis).

Thus there are two models of zakat management. Firstly, zakat is managed by the state in a department. Secondly, zakat is managed by non-government organizations (civil society) or quasi of government with reference to the rules set by the state. ${ }^{27}$ The first model, the collection and distribution of zakat set by government policy with respect to the needs of the community so that the zakat is similar tax to that performed in the secular states. This kind of zakat management system is directly, which means that Muslim citizens are obliged to pay this tax directly from their treasures, and those who do not fulfill their zakat obligation imposed sanctions.

While in the second model, the management of zakat is done by civil society voluntarily and the state is merely as a facilitator or regulator. Both models have their advantages and disadvantages. The weakness of the first model, the state is very dominant while people are not involved a lot. The second model, the community is very dominant and zakat collection was voluntary zakat so that revenues tend to be small.

From the history aspect of the Islamic government, the State directly involved in managing zakat. the Imam/Caliph easily controls the management of zakat directly. ${ }^{28}$ This mechanism has been going on since the time of Prophet Muhammad to Otsmani Dynasty. At the time of the Prophet sent Muadz bin Jabal to manage zakat in Yemen and he immediately picked up the zakat of the Muslim community directly. ${ }^{29}$ Muadz's role as state representative has the authority to collect zakat and distributed it to the poor as the embodiment of social justice. The authority of the state also determines the sustainability of zakat management based on the commands of the Qur'an Surah At- Tawbah [9] : 103 which reads: "Take alms of their wealth." In interpreting this verse, Kamaluddin bin Human, a Muhaqqiq from Madzhab of Hanafi said: "that of words of Allah : "take alms from their wealth...", requires taking it absolutely right by the ruler (Imam/Caliph), both property and inner possessions). ${ }^{30}$

Imam Ar Razi in interpreting Surah At-Tauba [9] : 60, he connects it with Surah At-Tauba [9] : 103. Ar Razi said: "This verse shows that to this zakat, the Imam/Caliph takes care of making and distribution and those who side with him (designated officer)". ${ }^{31}$ While Al Jashash argues that the collectionf of zakat is solely the obligation (right) of an Imam/Caliph. When issued by the obligatory directly to the poor, then it is not allowed. Because the right of an Imam/Caliph always remains in collecting and distributing zakat. It should not be transferred to others. ${ }^{32}$

In addition, another verse elaborates community groups those are eligible to receive zakat as in the Surah [9]: 60, the distribution of zakat is supplied to recipients of certain groups which implementation is done by the agency or institution.

In understanding the meaning of "Amil" in Surah At Tawbah [9]: 60, there is a strong hint about the presence of officers who collect and distribute zakat. Imam Qurtubi explains the meaning of Amil, namely those are assigned by Imam/Caliph to collect zakat and as a representative of the Imam. Therefore, it is no more entitled to send these officers other than the Imam/Caliph. ${ }^{33}$

In discussing this issue, Imam Nawawi said: "Mandatory for Imam to assign an officer who took zakat. Therefore, the Prophet and the Caliphs always assigned the zakat officers. This was done because there were those among men who own property but did not know what is obligatory to him. In addition, there was also stingy persons so making it mandatory for authorities to assign someone to pick it up". ${ }^{34}$

From the description above, it is clear that the reception and distribution of zakat is the obligation of the ruler (imam; in this case is the Islamic state caliphate). It is not allowed social institutions, education, foundations or similar to it to collect and distribute zakat.

There are theological reasons underlying the direct orders of those days: first, as a religious order and the second as a distribution of property to justice. Doctrine of zakat confirms the existence of economic

\footnotetext{
${ }^{27}$ Sigrid Faath (ed.), Islamische Stiftungen und Wohltaetige Einrichtungen mit entwicklungspolitischen Zielsetzungen in arabische Staaten (Hamburg: Deutches Orient-Institut, 2003).

${ }_{28}$ AlFitri, The Law of Zakat Management and Non-Governmental Zakat Collectors in Indonesia, “ in The International Journal of Not-forProfit Law, Vol. 8. (January, 2006), p.58.

${ }^{29}$ M. Shiddiq al-Jawi, Kejayaan Ekonomi pada Masa Khilafah Islamiyah available at www. Khilafah1924.org. in Hadith from Ibnu Abbas RA, he said: "when Rasulullah sent Muadz to Yaman, he said, "Muadz you actually going to visit a clan of the Ahl al-Kitab in Yemen. Once you have encountered them, you call them to say shahadah that there is no god but Allah and that Muhammad is the messenger of Allah. Then if they obey your invocation, tell them that God requires you to commit to pray five times a day and night, if they obey you, then tell them that God also requires zakat to them and then handed over to the poor that is around them ..." (Hadith. al-Bukhari, Muslim and Nasa'i). Kuntarno Noor Aflah and Mohd Nasir Tajang (Ed.), Zakat and Peran Negara, (Jakarta: Forum Zakat, 2006), p. 6.

${ }^{30}$ Anonymus, Mari Berzakat Dengan Benar, Weekly Bulletin Al-Ihtikam, $16^{\text {th }}$ Ed., (Surabaya : Lembaga Dakwah dan Kajian Strategi AlIhtikam, tt.), p.1

${ }^{31}$ Ibid.

${ }^{32}$ Ibid.

${ }^{33}$ Ibid, p. 2

${ }^{34}$ Ibid, p 2
} 
interests, which provide benefits to the poor in addition to the implementation of worship. This strategic role encourages countries to get involved, because the state has authority to protect its people from monopoly and responsibles to prosperous life.

Zakat is the worship of God and the embodiment of social justice, which is interpreted as teachings of worship that having two dimensions, namely mahdhah worship and ghayr mahdhah worship. Mahdhah worship means zakat has certain standard systems such as commodities, time and a certain amount to be paid. Therefore, especially for the literalist, aspects of zakat are more focused on these elements. While in ghayr mahdhah, zakat has a social function, namely the protection of the indigent and poor. This means that zakat has a role as revenue that is collected from the capable person (muzakki) for the benefit of poor people. Here, the zakat will intersect with social, economic and political aspects.

In Saudi Arabia, for example, because the state is firmly based on the Islamic law, zakat management has been set by law since $1951 .^{35}$ Then the individual person is still given the opportunity to distribute their zakat themselves directly to a maximum of half of the total obligatory zakat, while the left is submitted to the Ministry of Finance. However, for companies, zakat is paid to the Ministry of Finance. ${ }^{36}$

The role of the Ministry of Finance as a state institution, in collaboration with the Ministry of Social Affairs is in charge of distributing zakat to mustahik. Zakat system, for the Saudis, is the same as the tax, because zakat is synonymous with taxes. Being non-Saudi residents, they are exposed to tax liabilities that need to be paid. For the determination of mustahik, the state has produced standards of in-depth review by the Ministry of Social Affairs and Labor. This is where the role of the state is important, particularly in view of the priority interests of muzakki. ${ }^{37}$

In contrast to Saudi Arabia, Sudan has an interesting experience, which zakat is paid voluntarily before it was enacted in 1984. Obligation of zakat in Sudan is only for those Muslims who are inside and outside the country. The collection of zakat is done under the same roof with the tax collector. At the time of distribution, the Ministry of Finance and Economic Planning has a role in the distribution of zakat in accordance with National Fatwa Council decision. The role of state is dominant and involving the community in terms of supervision. This kind of zakat management system seems ideal where there is synergy between the community and the state. In terms of countries, it has priority programs to be solved, especially in the case of poor interest with the civil society that contribute to control.

Meanwhile in Malaysia, in terms of zakat, the Malaysian government supports the collection of zakat, which is done by private. The position of the government is only a facilitator and the person in charge. In the area of administration, management of zakat in Malaysia placed in the Assembly of Islam. Council of the Islamic Coordination is in a non departmental ministry. The role and function of non-departmental minister is to make strategic agency responsible directly to the Prime Minister. The Ministry of Islamic Council makes a very innovative breakthrough that is named Zakat Levy Center and Hajj Deposit. These two institutions now become a reference for some other countries. ${ }^{38}$

Zakat Levy Center officially opened on January 1, 1991 in Kuala Lumpur. But the ideas and concepts of Zakat Levy Center has started since May 1989. At the previous, the collection of zakat and donation are weak in Malaysia. Something that is very common due to the lack of personnel, inadequate systems and socialization of zakat that was never done. From a number of goals of Zakat Levy Center, there are two interesting matters. First, this model makes zakat payment convenient. Second, introduces the way in matters of corporate marketing and computer-based technology. Marketing tips and the position of Zakat Levy Center that is purely private, stimulate states in other parts of Malaysia to use the concept. Now, in addition to Kuala Lumpur, Zakat Levy Centers are also grown in five states, namely Melaka, Pahang, Selangor, Penang and Negeri Sembilan. The rest, ie, eight other states, they combine the functions of Baitul Maal. In Malaysia, zakat is not managed nationally (federally). The fourteen states in Malaysia, each is given the right to manage their own zakat. ${ }^{39}$

In terms of the management of this zakat, there are four policies of Malaysian government that can be recorded. First, the government approved the legal status and position of Zakat Levy Center as a company that only raises zakat funds. Second, allow the Zakat Levy Centre take $12.5 \%$ of the total zakat citation every year, to pay employee salaries and operating costs. Third, the government sets a tax deduction of zakat. And fourth, the government allocates funds to assist the Baitul Mal in eradicating poverty. ${ }^{40}$

\footnotetext{
${ }^{35}$ Royal Court Decision No. 17/2/28/8634 onl 29/6/1370H/7/4/1951, states: "Zakat accordance with Sharia is obligated to Saudis persons and companies."

${ }^{36}$ Kuntarno Noor Aflah,Op cit., pp. 33-34.

${ }^{37}$ Ibid, p.36

${ }^{38}$ Ismail Ibrahim and Elinah Abdullah, The Singapore Malay/ Muslim Community : Civic Traditions in a Multiracial and Multicultural Society in Gillian Koh and Ooi Giok Ling, et.al.,State Society Relations in Singapore, (Singapore : OxfordUniversity Press, 2000 ), pp. 54 55 .

${ }^{39}$ Erie Sudewo, Kebijakan Perzakatan : Kita and Negeri Tetangga, dalam Politik ZISWAF Kumpulan Esai , (Jakarta, CID and UI Press : 2008), p. 172

${ }^{40}$ Ibid., p. 178
} 
Moving on from the important role of state in the management of zakat, the relations between state and non-governmental institutions are very important. Their relationship is based on formal legal rules in achieving social justice. To achieve the objectives of zakat as a social justice, the system of state relations and civil society need to be implemented explicitly within the framework of good governance.

\section{Implications of Regulations on Zakat Management As Local Revenue in Aceh}

Enactment of zakat as a source of local revenue of Aceh and Regency/Municipality as provided for in Article 180 paragraph (1) letter d of Law Number 11 of 2006 on Governing of Aceh and Article 24 paragraph (2) Aceh Qanun No. 10 of 2007 on the Baitul Maal mentioned: "all income from zakat managed by Aceh Baitul Maal is a source of revenue of Aceh to be deposited into the General Treasury of Aceh". Similarly, the provisions of Article 25 paragraph (2): "all income from zakat managed by Baitul Maal of Regency/City is a source of revenue of the regency/municipality to be deposited into the Treasury General of Regency/City". It was originally thought to be a breakthrough, as the peculiarities of Aceh and the only one in Indonesia, but lately it causes serious problems, some pros and cons among the public.

In practice this is a dilemma, because as the revenue, zakat should be managed by the Department of Finance of Aceh, where the mechanism following the National Financial Management System. ${ }^{41}$ Zakat can only be disbursed if the Budget of Aceh has been verified/agreed, but if Income and Expenditure Budget of Aceh is delayed, then zakat becomes "hostage", this is a separate issue in the rules of Islamic jurisprudence. Supposedly, if Baitul Maal defined as the zakat manager, then zakat funds in the local revenue should be regulated specifically.

According to the Regulation of the Minister of Home Affairs Number 13 of 2006 on Regional Financial Management Guidelines, Article 1 stated: "Local Finance is all the local rights and obligations within the framework of local governance areas that can be valued in money including all forms of wealth associated with the rights and obligations of that region."

Based on that definition, the basic elements of regional finance consist of:

a. Regional rights (which can be valued in money);

b. Regional Obligations (which can be valued in money);

c. Wealth-related rights and obligations.

The regional rights in local finance is all rights attached to the region in accordance with the laws and regulations that are used in an attempt to fill their coffers.

Rights of the region includes, among others:

a. Local taxing rights (Act No. 28 of 2009 on Regional Taxes and Levies).

b. Rights to withdraw regional charges/dues (Act No. 28 of 2009 on Regional Tax and Retribution).

c. Rights to held loans (Act No. 33 of 2004 on Financial Balance between Central and Regional Finance).

d. Rights to acquire the balance of funds from the central government (Act No. 33 of 2004).

To the right of the Aceh region, in addition to the right of local taxes and retributions (number 1 and 2) would increase with the rights of zakat as a source of revenue. The obligation of region is also a part of the implementation of the central administration duties in accordance with state goals.

There are several implications of the enactment of zakat as local revenue:

a. Zakat received by the Baitul Maal can not be immediately distributed to the beneficiary (mustahik), because they have to wait for the ratification of the Regional Budget of the House of Representatives of Aceh or the House of Representatives of Regency/City;

b. Disbursement of Zakat funds should follow the pattern of financial management areas, so it must be through a mechanism Disbursement Warrant. As a result, disbursement of zakat by Baitul Maal often found by the Audit Board of the Republic of Indonesia each year, because it is not listed in the local income statement.

c. The search of zakat can not be accessed easily, because it has to go through the bureaucracy of local finance, then the public has perception that the Baitul Maal withhold disbursement of zakat.

d. This situation (point c) also affects the decline of public trust (muzakki) to pay zakat to the Baitul Maal.

e. If there is a procurement of goods and services, such as dhuafa's housing construction whose value is above Rp. 200.000.000, - (two hundred million rupiahs), it must be tendered in accordance to Presidential Regulation No. 70 of 2012 on the second Amendment of Presidential Regulation No. 54 on 2010 on Procurement of Government Goods/Services.

${ }^{41}$ Law No. 17 of 2003 on State Finance, ratified on March $9^{\text {th }}, 2003$. 
f. There will be a legal mess if there is a crime of embezzlement against zakat funds that have been recorded as Revenue (into the regional finance), then what laws are applicable, whether the Act No. 20 of 2001 on the Amendment Act No. 31 of 1999 on the Eradication of Corruption or Aceh Qanun No. 10 of 2007 on the Baitul Maal.

Meanwhile, people's understanding of zakat is set up in such a way in the Qur'an and Al-Hadith to be distributed to eligible asnaf (mustahik). To avoid collisions between the two provisions, then depositing a zakat to local cash as a local revenue should be so arranged or separated by placing them in a special account, while the distribution still follows or in accordance with Sharia provision.

On one hand, the determination of zakat as the local revenue has to consider the principles of Islamic law in its management, on the other hand, it must be compatible with the existing financial rules, distribution should be subject to the rules governing the Regional Financial Management. According to the former chief of Aceh Baitul Maal, Amrullah, zakat as part of the local revenue still leaves the problem. According to him, it is potential to become a crisis of regulations. ${ }^{42}$

According to Prof. Alyasa' Abubakar, former head of the Shari'a Agency in Aceh Province:

Management of Zakat funds should be treated specially, because the money is not the regional budget in general, and there are already rules on how to distribute it. Moreover, we must know the total amount of raised zakat, how much has been distributed, and how much funds remain after distribution. If all zakat funds included in governmental budgeting mecanism, it is affraid that the funds will be mixed with other source of revenue. To bridge the gap between the management of zakat based on religious rules and the management of zakat as a source of revenue in the budget system, then the government established an institution through Aceh Baitul Maal by Aceh Qanun No. 10 of 2007 on Baitul Maal. This institution will set what zakat that can be managed by the governmental budget system and which zakat should be distributed directly to mustahik (zakat recipients). ${ }^{43}$

Aceh Baitul Maal has ever tried to solve this problem by proposing that the zakat in Aceh Regional Revenue treated as a special issue. This proposal was ever presented in the discussion of Qanun draft of Baitul Maal. However, the House of Representatives of Aceh rejected it. The reason is that as Act No. 11 of 2006 only mentions the local income/revenue, not special local income/revenue.

Similarly, Governor Regulation No. 60 of 2008 on Mechanism of Zakat Management also refused to include zakat as a special source revenue. Therefore, Qanun No. 10 of 2007 on the Baitul Maal did not mention zakat as a Special source revenue. ${ }^{44}$

According to the former chief Baitul Aceh, Amrullah: Inclusion of zakat as a source of revenue in various statutory provisions with all legal consequences attached, particularly the regional financial regulations, is contrary to the essence of zakat that has been defined in the Qur'an. ${ }^{45}$

Then even if the provision of zakat implementation as Regional Revenue has been set in a number of Governor of Aceh regulations, but not all regency/city have make regulations on zakat implementationa. This means that the regency/city still need to be equipped with regulation at regency/city level, so it does not give rise to conflicts of complexity in accounting zakat as local revenues, does not result in a negative public perception, and not also reduce independency of Baitul Maal as amil agency and does not violate Islamic law on zakat. In fact, the practice of zakat as local revenue has not gone into effect yet on all 23 Baitul Maal of Regency/City. This occurs due to incomplete regulations in the form of Regent/Mayor Regulations and there are still some Baitul Maals at Regency/City level hesitant to implement it.

For Regency/City, ${ }^{46}$ central government also stipulates Regulation of the Minister of Home Affairs Number 37 of 2009. Yet for some Regencys/Cities, they have not already have derivatives regulation, so that those who have had no derivatives rules could not implement the Regulation of the Minister of the Home Affairs.

When compared with the provisions of Law No. 23 of 2011 concerning Zakat and Law No. 32 of 2004 on Regional Government and national regulations on financial management (especially on the original income/revenue), the determination of zakat as one of the sources of local income is only in Aceh. It is not only set the management of zakat, but also set other religious treasures in specific way. In contrast to the Law No. 23 of 2011 concerning zakat, zakat provision is not found as part of revenue source. Similar to the governing body that manage zakat and other religious treasures, the other regions/provinces outside Aceh are not managed by

\footnotetext{
${ }^{42}$ Article on Baitul Maal Aceh, October 2011.

${ }^{43}$ Harian Serambi Indonesia, Zakat merupakan PAD Khusus, Published on March $10^{\text {th }}, 2014$

44 Ibid.

${ }^{45}$ Ibid.

46 Since 1999, Aceh has grown for more regencys, up to 5 cities and 18 regencys. Available at http://id.wikipedia.org/wiki/Aceh, accessed on August $10^{\text {th }}, 2013$.
} 
the Baitul Maal but the National Board of Zakat and the Board of Waqf of Indonesia. Aceh is very different from the other regions.

Similarly to what is stipulated in Law No. 32 of 2004 on Regional Government, does not mention the right of the region to collect zakat, this right can be seen in the provisions of Article 180 paragraph (1) of Law No. 11 of 2006 on the Governing of Aceh, because zakat is one of the original income source then consequently zakat is part of the financial areas that must be managed and must be accounted for in accordance with the accounting principles of the financial management area.

According to Aidit Ghazali, in the modern Islamic state there are four sources of state revenue: (1) funds of Baitul Maal; (2) revenues from natural resources of society; (3) taxes; and (4) loans. ${ }^{47}$ Baitul Mal funds derived from sources of special wealth, which is zakat, and general sources of wealth that is fa'i, ushr, taxes, ghanimah, and other sources, which are not owned by individuals and submitted to the Baitul Maal. ${ }^{48}$

Shaykh Taqiyyuddin An Nabhani, in his book An Nizam Al Iqtishadi fi al Islam (1990), has explained the sources of income for Baitul Maal and its management rules. He says that the main sources to Baitul Maal are: fai', ghanimah/Anfal, kharaj, jizya, income of public property, income from the property of the state, usyuur, khums of Rikaz, mines, and zakat. ${ }^{49}$

However, Zakat is placed on a special cash in Baitul Maal, and only given to the eight ashnaf (groups) that have been mentioned in the Qur'an. Not in the slightest from the Zakat should be given to other than the eight ashnaf, either for state affairs, or the affairs of the people.

Imam (Caliph) might give the zakat based on the opinion and ijtihad to anyone from among the eight ashnaf. Imam (Caliph) is also entitled to give such property to one or more ashnaf, or share them all.

Based on the above description, the ulamas (scholars) and umara (leaders) in Aceh needs to devise regulations that specifically govern the management of zakat. It is started from collection to distribution procedures, without conflicting with religious rules, because the zakat is religious obligation, which is collected over a certain amount of special wealth, and distributed to anyone in particular, in a certain time. However, there is currently no specific mechanism in distributing zakat that confirms Islamic law but does not violate state law.

For that, the government needs to regulate in a form of qanun (local regulations) on zakat and its management, as the Aceh Qanun on Baitul Mal, does not govern the distribution of zakat. This regulation is important, for differing which is the government-run zakat and which is Baitul Maal-run zakat. State might regulate, but should not eliminate the role of communities in managing zakat. This is proven by the Constitutional Court Decision No. 86/PUU-X/2012, the test of Article 18 of Law Number 23 of 2011 concerning Zakat, whereas the content of the decision gives more space for the community and reduces the monopoly of the government in managing zakat funds.

\section{Conclusion}

In accordance with the discussion that was submitted in the foregoing chapter, it can be concluded regarding the authority of the Government of Aceh in managing Zakat as a source of local revenue, as follows:

1. The authorization of the Government of Aceh in managing zakat as Regional Revenue from the perspective of administrative law has a strong legal standing. It is the attribution of authority based on the 1945 Constitution of the Republic of Indonesia and Law Number 11 of 2006 on the Governing of Aceh. Nevertheless, the authority is not in line with Islamic law provisions contained in the Qur'an, hadith and the opinion of Islamic scholars, as well as that practiced in the time of the Prophet and the Caliph who collect and manage the zakat in the capacity as a ruler. In addition, Indonesia is not an Islamic state, despite the majority leaders of Indonesia are muslims, so the centralization regulation of zakat by the state (the government of Aceh) can not be done automatically.

2. Establishment of Zakat as Regional Revenue is not in line with the essence of zakat as a religious order, so that giving rise to a variety of legal implications that need to look for a solution that does not infringe either of the legal aspects of regional finance (state) and Islamic law. Even if the zakat would be applied as a source of local revenue, it must be regulater as a special source of local revenue, and its management should be specifically in order to reach the goals and objectives of the zakat.

\footnotetext{
${ }^{47}$ Aidit Ghazali, Development An Islamic Pespective. (Kuala Lumpur, Pelanduk Publications : 1990), pp. 95 - 96.

${ }^{48}$ Ghazali, ibid., pp. $47-48$.

${ }^{49}$ M. Shddiq al Jawi, Baitul Mal Tinjauan Historis and Konsep Idealnya, available at http://khilafah1924.org. Accessed on December $10^{\text {th }}$, 2013.
} 


\section{References}

[1]. Abubakar, Al Yasa, "Pelaksanaan Syariat Islam di Aceh (Sejarah dan Prospeknya)," see. Safwan Idris (et.al.), Syariat di Wilayah Syariat, (Banda Aceh: Dinas Syariat Islam dan YUA, 2002).

[2]. Zakat Pengurang pajak, kapan Berlaku?, http://mpu.acehprov.go.id/index.php? option=com content\&view=article\&id=78:zakatpengurang-pajak-kapan-berlaku\&catid

[3]. Aflah, Kuntarno Noor \& Tajang, Mohd Nasir (Ed.), Zakat dan Peran Negara, (Jakarta: Forum Zakat, 2006).

[4]. AlFitri, The Law of Zakat Management and Non- Governmental Zakat Collectors in Iindonesia, " in The International Journal of Not-for-Profit Law, Vol. 8. (January, 2006).

[5]. Al Jawi, M. Shiddiq, Baitul Mal Tinjauan Historis Dan Konsep Idealnya, http://khilafah1924.org,

[6]. Al-Khatib, Hasan Ahmad, al-Fiqh al-Muqarran (Kairo: Dar al-Ta'lif, 1957).

[7]. Anonim, Mari Berzakat Dengan Benar, Bulletin Mingguan Al-Ihtikam, $16^{\text {th }}$ Ed., (Surabaya : Lembaga Dakwah dan Kajian Strategi Al-Ihtikam, tt.).

[8]. Azhari, Muhammad Tahir, Negara Hukum Suatu Studi tentang Prinsip-prinsipnya Dilihat dari Segi Hukum Islam, Implementasinya pada Periode Negara Madinah dan Masa Kini, (Jakarta: Prenada Media, 2003).

[9]. Al-Ghazali, Muhammad (et.al), Nizam Itsbatt al-Da'wa wa Adillatuh fi al-Fiqh al-Islami wa al-Qanun, Cet. I, (Iskandariyyah: Dar al-Da'wah, 1996).

[10]. Atmosudirjo, S.Prajudi, Hukum Administrasi Negara, $10^{\text {th }}$ Ed., (Jakarta: Ghalia Indonesia, 1995).

[11]. Fajar ND, Mukti \& Achmad,Yulianto, Dualisme Penelitian Hukum Normatif \& Empiris, (Yogyakarta : Pustaka Pelajar, 2010).

[12]. Faath, Sigrid (ed.), Islamische Stiftungen und Wohltaetige Einrichtungen mit entwicklungspolitischen Zielsetzungen in arabische Staaten (Hamburg: Deutches Orient-Institut, 2003).

[13]. Ghazali, Aidit, Development An Islamic Pespective. (Kuala Lumpur, Pelanduk Publications : 1990).

[14]. Hasan, Ahmad, The Early Development of Islamic Jurisprudence (Islamabad: Islamic Research Institute, 1994).

[15]. Harian Serambi Indonesia, Zakat merupakan Pendapatan Asli Daerah Khusus, March $10^{\text {th }}, 2014$.

[16]. Hatta, Sri Gambir Melati, Beli Sewa sebagai Perjanjian Tak Bernama, Pandangan Masyarakat dan Sikap Mahkamah Agung Indonesia, (Bandung: Alumni, 1999).

[17]. Ibrahim, Ismail and Abdullah, Elinah, The Singapore Malay/ Muslim Community: Civic Traditions in a Multiracial and Multicultural Society in Gillian Koh and Ooi Giok Ling, et.al.,State Society Relations in Singapore, (Singapore, Oxford University Press : 2000).

[18]. Ibrahim, Johnny, Teori \& Metodologi Penelitian Hukum Normatif, (Malang : Bayumedia, 2011).

[19]. Lubis, M.Solly, Filsafat Ilmu dan Peneltian, (Jakarta : PT.Softmedia, 2012).

[20]. Manan, Bagir, Politik Perundang-Undangan dalam Rangka Mengantisipasi Liberalisasi Perekonomian, (Bandar Lampung: FHUNILA, 1996). Marbun, SF., Peradilan Administrasi Negara dan Upaya Administrasi di Indonesia, (Yogyakarta : Liberty, 1997).

[21]. Mutawalli, Abd. al-Hamid, Azmah al-Fikr al-Islamy fi al-'Asr al-Hadith (t.tp: al-Hay'ah al-Misriyyah al-Ammah li al-Kitab, 1985)

[22]. Muhammad, H. Rusjdi Ali, Revitalisasi Syari'at Islam di Aceh Problem,Solusi dan Implementasi Menuju Pelaksanaan Hukum Islam di Nanggroe Aceh Darussalam, (Ciputat : Logos Wacana Ilmu, 2003).

[23]. Nawawi, H. Hadari dan Martini, Himi, Penelitian Terapan, (Yogyakarta : Gajah Mada University Press), 1996

[24]. Nurlinda, Ida, Prinsip-Prinsip Pembaruan Agraria, Perspektih Hukum, (Jakarta : PT. Rajagrafindo Persada, 2009).

[25]. Republik Indonesia, Undang-Undang Dasar Negara Republik Indonesia Tahun 1945.

[26]. Republik Indonesia, Undang-Undang Nomor 44 Tahun 1999 tentang Penyelenggaraan Keistimewaan Provinsi Daerah Istimewah Aceh.

[27]. Republik Indonesia, Undang-Undang Nomor 17 Tahun 2003 tentang Keuangan Negara.

[28]. Republik Indonesia, Undang-Undang Nomor 32 Tahun 2004 tentang Pemerintah Daerah.

[29]. Republik Indonesia, Undang-Undang Nomor 11 Tahun 2006 tentang Pemerintahan Aceh.

[30]. Republik Indonesia, Undang-Undang Nomor 23 tahun 2011 tentang Pengelolaan Zakat.

[31]. Sudewo, Erie, Kebijakan Perzakatan : Kita dan Negeri Tetangga, dalam Politik ZISWAF Kumpulan Esai , (Jakarta, CID dan UI Press : 2008).

[32]. Soemitro, Ronni Hanitijo, Metodologi Penelitian Hukum dan Jurimetri, (Jakarta : Ghalia Indonesia, 1990),

[33]. Soerjono Soekanto dan Sri Mamuji, Penelitian Hukum Normatif, (Jakarta: Rajawali, 1985).

[34]. Wehr, Hans, A Dictionary of Modern Writen Arabic, J. Milton Cowan (ed.), (Wesbaden : Otto Harrassowitz, 1971). 